NJE Vol. 36: 46-53, 2020

Nigerian Journal of Entomology

Published by the Entomological Soc. of Nig.

www.esnjournal.com.ng

DOI.10.36108/NJE/0202/63.01.50

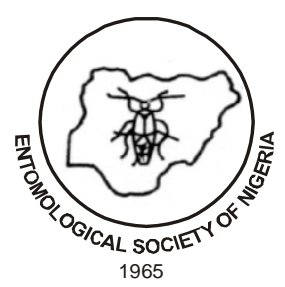

\title{
Biocidal Activities of Seed Oils of Jatropha curcas and Moringa oleifera on Development of African Maize Stalk borer, Busseola fusca Fuller (Lepdoptera: Pyralidae)
}

\author{
Sule, H. $^{{ }^{*}}$, Peter, E. $^{2}$ and Ibrahim, K. $^{1}$ \\ ${ }^{I}$ Department of Crop Protection, Bayero University Kano, Nigeria. \\ ${ }^{2}$ Department of Agronomy, Federal University Gashua, Yobe State, Nigeria
}

\begin{abstract}
Laboratory experiment was conducted at the Department of Crop Protection Laboratory, Faculty of Agriculture, Bayero University, Kano, in order to assess the effect of oils obtained from the seeds of Jatropha curcas and Moringa oleifera on African Maize Stalk Borer (Busseola fusca Fuller). The effects of the plant seed oils on larvae mortality, pupae and adult emergence were tested on freshly cut leaves/stem of maize 3-4 cm long) and treated with the prepared plant oils at various concentrations $(10,20$, and $30 \%)$ and control $(0 \%)$. The experiment was laid out in a completely randomized design and replicated four times. The results showed that both plant seeds oils were lethal to the developmental stages of B. fusca, causing mortality (21\%) to the larvae, and subsequently preventing and/or suppressing pupae (2.08) and adult emergence (1.95). Treatment at 30\% concentration was found to be more lethal to all the developmental stages of the test insect. Based on the findings of this study, it is recommended that any of the plant seed oils at $30 \%$ concentration could be used to manage B. fusca.
\end{abstract}

Keywords: Jatropha curcas, Moringa oleifera, seed oil, larvae, African maize stalk borer, Busseola fusca.

\section{INTRODUCTION}

Busseola fusca (Fuller), also known as the African Maize Stalk Borer (AMSB), is a moth, indigenous to tropical Africa (Harris and Nwanze, 1992). It is considered the most important pest of maize in Sub-Saharan Africa (SSA). This pest has been reported to

*Correspondence email:

hsule.cpp@buk.edu.ng cause great damage and yield losses across Africa (Robert et al., 2014). These result from mechanical damage to maize plants (Amudavi et al., 2009). The damage is heightened by the destruction of the growing points in the whorl, causing dead heart situation, loss of photosynthetic leaf area due to foliar feeding, lodging due to burrowing into the stem and extensive damage to young kernels by second and third instar larvae 
(Ofor et al., 2009). Damage resulting from the stem borers' infestation on maize plant can cause between $20-40 \%$ losses during cultivation, and between 10-100\% during postharvest and storage (Bosque-perez, 1990; Robert et al., 2014; Kendall et al., 2014). As such the damage caused by $B$. fusca on maize crop plant had contributed to food shortage and affected self-sufficiency.

In Nigeria, controlling B. fusca is primarily through the usage of chemical control. This approach, despite being effective and popular among farmers, has its attendant problems such as environmental pollution, pesticide residue in food chain, development of insecticide resistance, and toxicity to non-target organisms and is not affordable to most poor resource farmers (Clieve, 2003). In recent times, much attention has been given to biopesticides, as a favoured alternative source of protectant against insect pests both in the field and in the store. The use of botanicals for the control of agricultural pests are considered to be environmentally friendly and cost effective (Rausell et al., 2000). Besides they are readily available and affordable which makes them more acceptable to farmers in developing countries, especially, Nigeria; where they readily incorporated as a major component of integrated pest management programme (Mukhtar et al., 2018). In line with this trend of research, this study investigated the lethal effects of oils of $J$. curcas and $M$. oleifera seeds on the immature stages and general development of B. fusca.

\section{MATERIALS AND METHODS}

\section{Experimental Site}

The study was carried out in the Entomology Laboratory of the Department of Crop Protection, Faculty of Agriculture, Bayero University, Kano, Nigeria. This location lies within Longitude $9^{\circ} 30^{\prime} \mathrm{N}$ and Latitude $8^{\circ} 42^{\prime} \mathrm{E}$ at about $481 \mathrm{~m}$ above sea level (Mustapha et al., 2017).

\section{Plant Material Collection, Preparation and Extraction of Seed Oils}

The plants materials ( $J$. curcas and $M$. oleifera) evaluated for insecticidal activity against $B$. fusca were collected from Orchard of Faculty of Agriculture, Bayero University, Kano (B.U.K). The seeds of the plant materials were dried under shade and decorticated to obtain the kernels. Thereafter, the dried seeds were milled using electric grinder to obtain a fine powder. Oil extraction from the seeds was carried out in the Department of Animal Science Laboratory, B.U.K using Soxhlet Extraction Apparatus. The pulverized plant samples (100 $\mathrm{g}$ each) were dissolved in petroleum ether $(250 \mathrm{~mL})$, the system was heated for about $5 \mathrm{~cm}$ above a hot electric hot plate while cold water was allowed to flow in and out of the condenser compartment to cool the system. After many refluxes for about 3 hours, the petroleum ether evaporated leaving behind oil-content inside the container.

\section{Larval Collection}

The larvae used for the study were collected by handpicking and beat sampling techniques from Pesticide free Maize plants at the Farm/Orchard of Faculty of Agriculture, Bayero University, Kano. The larvae were placed in a transparent plastic container measuring $25 \times 20 \mathrm{~cm}$ and $8 \mathrm{~cm}$ deep lined with tissue paper and covered with muslin cloth and transported to the Laboratory.

\section{Larval Rearing}

The collected larvae of $B$. fusca were reared in groups of 10 individuals in transparent plastic cup measuring of $8.5 \mathrm{~cm}$ in diameter 
at the top, $6 \mathrm{~cm}$ in diameter at the bottom and $5 \mathrm{~cm}$ in depth lined with tissue paper and covered with muslin cloth. The larvae were fed with fresh young stalks and succulent leaves of maize. These food materials were changed and replaced with fresh ones every 2 days. The larvae were allowed to pupate in same containers. After emergence, 50 adults were transferred to a cage measuring $45 \mathrm{x}$ $45 \mathrm{~cm}$ for mass breeding to obtain homogenous and sufficient population for the experiment. Cotton wool soaked with $10 \%$ honey solution were provided as food. Tissue papers were spread and hanged and also a small fresh branch of maize plant carrying young leaves and stalk were dipped in a bottle containing water to keep it turgid as an oviposition site to the adult insect inside the cage. These branches were renewed daily to attract the moths for egg laying.

Hatched neonates of B. fusca (1st instar larvae) were collected with camel hair brush and introduced onto young leaves of maize in a transparent plastic cup of $8.5 \mathrm{~cm}$ in diameter at the top, $6 \mathrm{~cm}$ in diameter at the bottom and $5 \mathrm{~cm}$ in depth lined with moist filter papers. Feeding and changing of food materials were continued up to the stage needed for the termination of experiment $\left(3^{\text {rd }}\right.$ instar larvae).

\section{Plant Seed Oil Concentration Preparation}

The plant oil extracts were diluted with petroleum ether as a carrier solvent in a bottle to obtain the different serial concentration levels as follows:

i. $\quad 500 \mu \mathrm{l}$ of Jatropha oil into $5000 \mu \mathrm{l}$ of petroleum ether (10\% concentration)

ii. $\quad 1000 \mu \mathrm{l}$ of Jatropha oil into $5000 \mu \mathrm{l}$ of petroleum ether $(20 \%$ concentration) iii. $\quad 1500 \mu \mathrm{l}$ of Jatropha oil into $5000 \mu \mathrm{l}$ of petroleum ether $(30 \%$ concentration)

iv. $\quad 500 \mu \mathrm{l}$ of Moringa oil into $5000 \mu \mathrm{l}$ of petroleum ether (10\% concentration)

v. $\quad 1000 \mu \mathrm{l}$ of Moringa oil into $5000 \mu \mathrm{l}$ of petroleum ether $(20 \%$ concentration)

vi. $\quad 1500 \mu \mathrm{l}$ of Moringa oil into $5000 \mu \mathrm{l}$ of petroleum ether $(30 \%$ concentration).

\section{Laboratory Bioassay and Assessment of Mortality}

The experiment was conducted for $72 \mathrm{hrs}$ under laboratory condition at room temperature of $24 \pm 2^{\circ} \mathrm{C}$. Freshly collected young leaves/stem of maize were cut into pieces of 3-4 cm long. Twenty pieces of the cut plants parts were uniformly sprayed with different concentration $(10 \%, 20 \%$ and $30 \%)$ of $J$. curcas and M. oleifera seed oils with control (petroleum ether), and allow to dry for 30 minutes to allow the petroleum ether evaporate and/or dry off under laboratory condition, and then placed in a plastic container measuring $8.5 \mathrm{~cm}$ at the top, $6 \mathrm{~cm}$ in diameter at the bottom and $5 \mathrm{~cm}$ deep lined with tissue paper. Thereafter 10 3rd instar larvae of B. fusca from the reared specimens were collected using camel brush from maize leaves and dissected stalks and introduced into the container covered with muslin cloth and allowed to feed. The experiment was laid out in a complete randomized design with 4 replications.

Dead larvae in each of the treatment replicate were counted and recorded at 24, 48 and 72 hours after introduction. The larvae were considered dead when they were unable to move when prodded with a fine hairbrush; after which they were removed from the test container. 


\section{Assessment of Pupal and Adult Emergence}

Number of pupa that emerged were counted and recorded in each of the treatment replicates 3 to 5 weeks after introduction of the test larvae or after initial infestation. Conversely, number of adult insect that emerged were also counted and recorded after a pupal period of 7 to 14 days in each of the treatment replicates.

\section{Data Analysis}

The original mortality data were corrected by Abbott's formula for natural mortality in untreated controls (Nwanko et al., 2015). The corrected mortality data obtained in percentages were arc-sine transformed and data obtained from pupa and adult emergence that was recorded as zero, along with other numerical data; were transformed with $\sqrt{n+1}$. The transformed data were subjected to two way analysis of variance (ANOVA) using Genstat 17th Edition Software. Differences between means were separated using Turkey's HSD test at 95\% level of probability.

\section{RESULTS}

Table 1 presents the effects of seed oils and concentration of Jatropha curcas and Moringa oleifera on the larvae of $B$. fusca. The results show no significant difference $(\mathrm{P}>0.05)$ in the mortality caused by both plant oils to larvae of B. fusca at 24, 48 and 72 hours exposure. Moreover, the effect of time of exposure at $24 \mathrm{hr}$ did not cause significant mortality $(\mathrm{P}>0.05)$ at 30,20 and
$10 \%$ concentrations; but $30 \%$ concentration caused higher mortality and was significantly different $(\mathrm{P}<0.05)$ from the control $(0 \%)$. At 48 and 72 hours, the same trend was observed among the concentrations. The result indicates that mortality caused by the plant seed oils increases with time and concentration levels as more mortality was recorded after $72 \mathrm{hr}$ and 30\% concentration when compared with the remaining treatments.

The results obtained on the effect of plant seed oils and concentrations on the pupa emergence of B. fusca are shown in Table 2. The results showed no significant difference $(\mathrm{P}>0.05)$ in the number of pupae that emerged between the two plant seed oils. When concentration was considered, 30\% concentration recorded less number of pupae emergence but was not statistically different ( $\mathrm{P}>0.05$ ) from 20 and $10 \%$ concentrations. However, all the concentration levels were statistically different $(\mathrm{P}<0.05)$ with the control which recorded more pupae emergence.

Table 3 shows the emergence of adult $B$. fusca exposed to oils of $J$. curcas and $M$. oleifera seeds. The results showed no significant difference $(\mathrm{P}>0.05)$ in the number of adults that emerged between the two plant oils. Also, the number of adult emergence was not significantly different $(\mathrm{P}=0.05)$ from each other at all concentration levels except from the control. However $30 \%$ concentration recorded less number of adult emergence when compared with the remaining treatments. 
Table 1: Percentage Larva Mortality of B. fusca at 24, 48 and 72 hours after Treatment

\begin{tabular}{lccc}
\hline & \multicolumn{3}{c}{ Mean larvae Mortality (\%) } \\
\hline Treatments & $\mathbf{2 4 ~ H r s}$ & $\mathbf{4 8 ~ H r s}$ & $\mathbf{7 2 ~ H r s}$ \\
\hline Plant seed oils & & & \\
Jatropha curcas & $3.3\left(10.5^{\mathrm{a}}\right)^{*}$ & $15.4\left(23.1^{\mathrm{a}}\right)$ & $21.3\left(27.5^{\mathrm{a}}\right)$ \\
Moringa oleifera & $7.5\left(15.9^{\mathrm{a}}\right)$ & $14.6\left(22.5^{\mathrm{a}}\right)$ & $18\left(25.1^{\mathrm{a}}\right)$ \\
SED & 4.302 & 5.03 & 5.29 \\
Concentration (\%) & & & \\
10 & $4.4\left(12.08^{\mathrm{ab}}\right)$ & $9.2\left(17.71^{\mathrm{ab}}\right)$ & $19.9\left(26.49^{\mathrm{a}}\right)$ \\
20 & $8\left(16.45^{\mathrm{ab}}\right)$ & $27.9\left(31.90^{\mathrm{a}}\right)$ & $30.8\left(33.75^{\mathrm{a}}\right)$ \\
30 & $17\left(24.35^{\mathrm{a}}\right)$ & $36.3\left(37.04^{\mathrm{a}}\right)$ & $42\left(40.39^{\mathrm{a}}\right)$ \\
Control $(0)$ & $0.00\left(0.00^{\mathrm{b}}\right)$ & $0.64\left(4.61^{\mathrm{b}}\right)$ & $0.64\left(4.61^{\mathrm{b}}\right)$ \\
SED & 6.08 & 7.11 & 7.48 \\
\hline
\end{tabular}

*Figures in parenthesis are arc sine values to which SED are applicable. Means followed by same superscripts within same column are not significantly different $(\mathrm{P}<0.05)$ Turkey's HSD test.

Table 2: Number of pupae of $B$. fusca at 3-5 weeks after treatment

\begin{tabular}{lc}
\hline Treatment & Mean No. Pupae \\
\hline Plant seed oils & $1.93^{\mathrm{a}}$ \\
Jatropha curcas & $2.08^{\mathrm{a}}$ \\
Moringa oleifera & 0.1605 \\
SED & \\
Concentration (\%) & $1.86^{\mathrm{b}}$ \\
10 & $1.77^{\mathrm{b}}$ \\
20 & $1.47^{\mathrm{b}}$ \\
30 & $2.93^{\mathrm{a}}$ \\
Control (0) & 0.2270 \\
\hline
\end{tabular}

Means followed by same superscripts within same column are not significantly different $(\mathrm{P}>0.05)$ Turkey's HSD test.

Table 3: Mean Adult Emergence of B. fusca on maize plant after a pupal period of 7 to 14 days

\begin{tabular}{lc}
\hline Treatment & Mean Adult Emergence \\
\hline Plant seed oils & \\
Jatropha curcas & $1.72^{\mathrm{a}}$ \\
Moringa oleifera & $1.95^{\mathrm{a}}$ \\
SED & 0.1607 \\
Concentration (\%) & \\
10 & $1.47^{\mathrm{b}}$ \\
20 & $1.61^{\mathrm{b}}$ \\
30 & $1.36^{\mathrm{b}}$ \\
Control (0) & $2.891^{\mathrm{a}}$ \\
SED & 0.2273 \\
\hline
\end{tabular}

Means followed by same superscript within same column are not significantly different $(\mathrm{P}>0.05)$ Turkey's HSD test. 


\section{DISCUSSION}

The results of this study showed that oils obtained from $J$. curcas and M. oleifera seeds had negative effects on the development of B. fusca, causing larvae mortality and subsequently preventing and/or suppressing pupal and adult emergence. These results are in agreement with previous reports by Dubey et al. (2010), Gupta et al. (2010) and Arnubio et al. (2006), who reported that various extracts of neem, physic nut, tobacco and pyrethrum flower can be used to control Lepidopteran stem borer species. Also, Harinder and Klaus (2009) reported that leaf and seed extracts of various botanicals can be highly toxic to larvae of $B$. fusca.

The lethal activity of the two biopesticides on the development of $B$. fucas may be caused by insecticidal properties of the two plant seed oils. Previous studies conducted with plant oils have demonstrated their larvicidal and antifeedant activity, capacity to delay development, adult emergence and fertility, as well as deterrent effects on oviposition (Naumann and Isman, 1995; Oyedele et al., 2000; Lengai et al., 2020), and arrestant and repellent action (Landolt et al., 1999).

The reports of Van der vossen and Mkamilo (2007), showed that Jatropha seed oil contains toxic compounds such as esters diterpenoid 12-deoxy-16-hydroxy-phorbol and curcin; which have pesticidal properties against insects such as the cotton bollworm (Helicoverpa armigera) and the cowpea bruchid (Callosobruchus maculatus). It has also been shown that Moringa seed oil contain a cocktail of fatty acids; Linoleic, Linolenic, Oleic (Leone et al., 2016) which are known to be toxic to insects and cause mortality.

The findings of the current study are consistent with those of Asmare et al. (2011) who investigated the efficacy of some botanicals on stem borers B. fusca (Fuller) and Chilo partellus (Swinhoe). Tadele (2013), investigated the effects of different botanical insecticide strategy against $B$. fusca under laboratory conditions and shown that methanol extracts of Jatropha oil containing phorbol esters have strong insecticidal effects against larvae of field insect pests (Asmare et al., 2011). Plant oils are volatile natural complex secondary metabolites characterized by a strong odor having pesticidal potential (Chang and Cheng, 2002). The findings of this study clearly shows that insecticidal activity of plant seed oils depend on the concentration of the plant oil in the solution as seen in the effect of various concentrations of the plant oils on the development of $B$. fusca. Bamaiyi et al. (2007) showed that higher concentrations and longer exposure periods were needed to achieve appreciable levels of control, which concurred with the results obtained in this study. Oparaeke and Dike (2005), Asawalam and Emosairue (2006) in separate studies reported that the efficacy of various plant products tested against storage insect pests' increase with increasing dose of plant products.

\section{CONCLUSIONS AND RECOMMENDATIONS}

The results showed that both plant seed oils were found to be lethal to B. fusca. $30 \%$ concentration is found to be more lethal to all the developmental stage of the test insects. Based on the findings of this study, it is recommended that any of the plant seed oils at $30 \%$ concentration could be used to manage $B$. fusca.

\section{REFERENCES}

Amudavi, D. M., Khan, Z. R., Wanyama, J. M., Midega, C. A. O., Pittchar, J., Nyagau, I. M., Hassanali, A. and Pickelt, 
J. A. (2009). Assessment of technical efficiency of teachers in the uptake and dissemination of push-pull technology in western Kenya. Crop Prot. 28:987-996.

Arnubio, V., Brigitte, F., Herve, G., Diego, F. M., Maria, F. G. and Paul, C. (2006). Effect of Jatropha gossypiifolia leaf extracts on three Lepidoptera species. Rev. Colomb. Entomol., 32:45-48.

Asawalam, E.F. and Emosairue, S.O. (2006). Comparative efficacy of Piper guineense Schum and Thonn and Primiphos methyl on Sitophilus zeamais (Motschulsky). Trop. Subtrop. Agroecosyst. 6:143-148.

Asmare, D., Emana, G., Ferdu, A. and Asmare, A. (2011). Efficacy of some botanicals on stem borers Busseola fusca (Fuller) and Chilo pertellus (Swinhoe) on Sorghum in Ethiopia Under field conditions. Biopesticides International. 7(1): 2434.

Bamaiyi, L. J., Ndams, I. S., Toro, W. A. and Odekina, S. (2007). Laboratory evaluation of mahogany (Khaya senegalensis Desv.) seed oil and powder for the control of Callosobruchus maculatus (Fab.) (Coleoptera: Bruchidae) on stored cowpea. Journal of Entomology. 4(3):237-242.

Bosque-Perez, N. A. (1995). Major insect pests of maize in Africa: Biology and control. IITA Research Guide 30. 2nd Ed. Training Program, International Institute of Tropical Agriculture (IITA), Ibadan. Nigeria, 30p.

Chang, S. T. and Cheng, S. S. (2002). Antitermite activity of leaf essential oils and their constituents from Cinnamomum osmophloeum. J. Agric. Food Chem., 50: 1389-1392.

Clieve, J. (2003). Global review of commerciallized transgenic crops: 2002 feature: B.T maize (ISAAA Brief No.29). Ithaca, N.Y: international service for the acquisition of Agri-Biotech Application. https://www.isaaa.org/resources/publication s/briefs/29/download/isaaa-brief-292003.pdf

Dubey, N. K., Ravindra, S., Ashok, K., Priyanka, S. and Bhanu, P. (2010). Prospects of botanical pesticides in sustainable agriculture. Curr. Sci. 98: 479480.

Egbuche, C.M. and Ukonze, C.B. (2015). Moringa oleifera and Annona muricata seed oil extracts as biopesticides Against the second and fourth larval instar of Aedes aegypti L. (Diptera: Culicidae). Journal of Biopesti-cides. 8(1):56-61

Gupta, S., Kalpana, H. and Pandey, I. P. (2010). Effect of insecticides against Chilo pertellus (Swinhoe) damaging Zea mays (Maize). Int. J. Parasitol. Res., 2: 4-7.

Harinder, P. M. S. and Klaus, B. (209). Jatropha curcas, a promising crop for the generation of biodiesel and value added crop products. Eur. J. Lipid Sci. Technol. 111: 773-787.

Harris, K. M. and Nwanze, K. F. (1992). Busseola fusca (Fuller), the African maize stem borer: a handbook of information. Information Bulletin \# 33. ICRISAT. Oxon, UK: CABI. $92 \mathrm{p}$.

Kendall, H., Tania, Y., Darren, J. K. and Noboru, O. (2014). Busseola fusca (African Stem Borer). Harvest Choice: Pest Geography. University of Minnesota, USA. pp. 1-6.

Landolt, P. J., Hofstetter, R. W. and Buddick, L. L. (1999). Plant essential oils as arrestants and repellents for neonate larvae of the Codling moth (Lepidoptera: Tortricidae). Environ. Entomol., 28: 954960.

Lengai, G.M.W., Muthomi, J.W. and Mbega, E.R. (2020). Phytochemical activity and role of botanical pesticides in pest management for sustainable agricultural crop production. Scientific African, 7(e00239): $1-13$. https://doi.org/10.1016/j.sciaf.2019.e00239.

Leone, A. Spada, A., Battezzati, A., Schiraldi, A., Aristil, J. and Bertoli, S. (2016). Moringa oleifera Seeds and Oil: Characteristics and Uses for Human Health. International Journal of Molecular Sciences. 17(2141):1-14.

Mukhtar Y., Abdu, K., Abdulkadir A. I., Galalain A.M., Maigari A. K., and Yunusa U. M. (2018). Sustainable use of 
botanical products in plant protection as a promising panacea to integrated pests management and control: issues, challenges, benefits and future prospects. International Journal of Advanced Academic Research| Sciences, Technology \& Engineering. 4(4): 66-67.

Mustapha, A.A., Lawan, B.A., Dawaki, M.U., Magaji, M.J. and Abdulwahab, M. (2017). Solubility of N.P.K. and $\mathrm{pH}$ Variability as influenced by Mineral fertilizer and Organic amendment on sandy loam in Kano State. Savannah Journal of Agriculture, 12(2); 30-35.

Naumann, K. and Isman, M. B. (1995). Evaluation of neem, Azadirachta indica seed extracts and oils as oviposition deterrents to noctuid moths. Entomol. Exp. Appl., 76: 115-120.

Ofor, M. O., Ibeawuchi, I. I. and Oparacka A. M. (2009). Crop protection problems in production of maize and guinea corn in Northern guinea savannah of Nigeria and control measures. Nature and Science: 7(12); 8-14

Oparaeke, A. M. and Dike, M. C. (2005). Monodora myristica (Gaertn), Dunal (Myristicaceae) and Allium cepa L. (Liliaceae) as protectants against cowpea seed Bruchid, Callosobruchus maculatus (F.) infesting stored cowpea seeds. Niger. J. Entomol., 22: 84-92.
Oyedele, A. O., Orafidiya, L. O., Lamikanra, A. and Olaifa, J. I. (2000). Volatility and mosquito repellency of Hemizygia welwitschii oil and its formulations. Insect Sci. Appl., 20:123-128.

Rausell, C., Martunez-Ramirez, A. C., Garia, R. I. and Real, M. D. (2009). A blinding site for Bacillus thuringiensis Cry1Ab toxin is lost during larval development in two forest pests. Applied environmental microbiology, 66:1553-1538.

Robert, W.N., Kirui, C.S., Cheramgoi, E., Chirchir, E. and Mwale, R. (2014). Damage of stem borer species to Zea mays L., Sorghum bicolor L. and three refugia graminae. African Journal of Food Science and Technology, 5(20):37-45.

Tadele, S. (2013). Effects of different plant powders for their use in a botanical insecticide strategy against Busseola fusca (Fuller) (Lepidoptera: Noctuidae) under laboratory condition. Int. J. Agric. Sci. Res., 2(12): 322-325.

Van der Vossen, H.A.M. and Mkamilo, G. S. (2007). Plant Resources of Tropical Africa 14 vagetables oils. PROTA Foundation. Wagningen, Netherlands/Back. Huys Publisher, Laden, Netherlands/CTA, Wageningen, Netherlands, pp. 226-237.

NJE Vol. 36: 46-53, 2020

Nigerian Journal of Entomology

Published by the Entomological Soc. of Nig.

www.esnjournal.com.ng

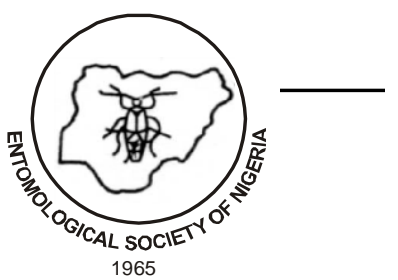

DOI.10.36108/NJE/0202/63.01.50 